\title{
SISTEM INFORMASI AKUNTANSI PENGELOLAAN PIUTANG USAHA UNTUK MENYAJIKAN PERNYATAAN PIUTANG (OPEN ITEM STATEMENT) PADA PT CHANDRA PUTRA GLOBALINDO
}

\author{
Retno Triana $^{1)}$, Heni Sulistiani ${ }^{2)}$, Neneng ${ }^{3)}$ \\ ${ }^{1,3)}$ Sistem Informasi Akuntansi, Universitas Teknokrat Indonesia \\ ${ }^{2)}$ Informatika, Universitas Teknokrat Indonesia \\ Jl. H.ZA Pagaralam, No 9-11, Labuhanratu, Bandarlampung \\ Email : trianaretno23@gmail.com ${ }^{1)}$,henisulistiani@teknokrat.ac.id ${ }^{2)}$,neneng060880@gmail.com ${ }^{3)}$
}

\begin{abstract}
Abstrak
Piutang merupakan aktiva lancar yang sangat penting perputarannya dalam kegiatan usaha. PT Chandra Putra Globalindo merupakan salah satu perusahaan dagang yang menyalurkan pupuk pestisida ke berbagai kantor atau toko di Propinsi Lampung. Kendala yang dihadapi dalam proses pengelolaan piutang usaha pada PT Chandra Putra Globalindo yaitu dalam pembuatan laporan pernyataan piutang masih dilakukan dengan cara posting manual satu persatu untuk setiap debitur. Untuk itu diperlukan pengelolaan piutang yang efektif agar dapat terjaga keamanannya dan dapat menghasilkan informasi yang akurat serta jumlah dana yang diinvestasikan di dalam piutang tidak mengganggu aliran kas sehingga perusahaan dapat mencapai laba maksimal yang diharapkan. Penelitian ini mengusulkan sebuah sistem yang digunakan untuk pengelolaan data piutang agar dapat melakukan pengelolaan data pengguna, pengelolaan data barang, mencetak rincian daftar barang, pengelolaan data daftar pelanggan, pengelolaan data pesanan, pengelolaan data retur, pengelolaan transaksi penerimaan dan pelunasan piutang serta berdasarkan data yang tersimpan dalam database dapat menghasilkan laporan penjualan dan laporan faktur yang belum lunas (open item statement). Pengujian sistem dilakukan dengan menggunakan Standar ISO 9126-1.
\end{abstract}

Kata kunci: Piutang, faktur, akuntansi

\section{Pendahuluan}

Piutang merupakan aktiva lancar yang sangat penting perputarannya dalam kegiatan usaha. Kas yang merupakan bentuk dari perputaran piutang diperlukan oleh perusahaan untuk membiayai kegiatan (Sidik dan Widiawati, 2016). Sebagian besar piutang timbul dari penyerahan barang dan jasa secara kredit kepada pelanggan (Hery, 2016). Kendala yang sering dihadapi pada perusahaan yang melakukan transaksi secara kredit adalah di perputaran piutang, yang menyebabkan arus masuk sumber dana dapat tersendat. Salah satu kendala tersebut adalah tidak efektifnya sistem pengelolaan/ manajemen piutang yang berjalan.

Sehingga diperlukan pengelolaan piutang yang efektif agar dapat terjaga keamanannya dan dapat menghasilkan informasi yang akurat serta jumlah dana yang diinvestasikan di dalam piutang tidak mengganggu aliran kas sehingga perusahaan dapat mencapai laba maksimal yang diharapkan.

PT Chandra Putra Globalindo merupakan salah satu perusahaan dagang yang menyalurkan pupuk pestisida ke berbagai kantor atau toko di Propinsi Lampung. Dalam pengolahan data piutang usahanya, masih dilakukan dengan cara mengentrikan data transaksi ke aplikasi spreadsheet dan wordprocessing. Begitu juga dalam pembuatan laporan masih menggunakan aplikasi tersebut. File-file dari laporan transaksi disimpan dalam media penyimpanan komputer, nama file disesuaikan dengan jenis laporan yang dibuat. Misal laporan penjualan, jurnal retur penjualan, jurnal penerimaan kas, buku besar pembantu piutang, dan lain sebagainya.

Dari transaksi yang terjadi, secara periodik akan dihasilkan pernyataan faktur yang belum dilunasi (open item statement). Kendala yang dihadapi dalam proses pengelolaan piutang usaha pada PT Chandra Putra Globalindo yaitu dalam pembuatan laporan pernyataan piutang masih dilakukan dengan cara posting manual satu persatu untuk setiap debitur. Hal tersebut tentu saja mengakibatkan keterlambatan dalam penyajian informasi serta waktu yang dibutuhkan untuk melakukan pencarian data posting dan penyimpanan data yang masih belum terpusat.

Beberapa penelitian tentang pemanfaatan sistem informasi untuk pengelolaan piutang usaha pernah diusulkan. Sukendar, Heri dan Selvia (2010) membuat sebuah sistem informasi akuntansi untuk membantu proses penjualan, piutang dan penerimaan kas. Sistem tersebut mampu menangani masalah perusahaan tentang sering terjadinya kealpaan dalam hal pencatatan piutang dan proses penagihan piutang. Noerlina dan Ratna (2006), pernah merancang sebuah sistem informasi akuntansi penjualan dan piutang dagang pada PT SAAG Utama. Sistem yang dirancang mampu mengatasi permasalaha perusahaan dalam hal pencatatan transaksi penjualan dan piutang dagang yang dirasa kurang efektif dan efisien, sehingga dapat juga membantu manajemen dan karyawan dalam melaksanakan pekerjaannya.

Hendarti dan Margareta (2008) membuat sebuah sistem penjualan kredit dan pelaporannya, sehingga mampu 
mengatasi permasalahan mengenai data piutang yang sudah dan akan jatuh tempo serta pengiriman barang yang sering mengalami keterlambatan.

Untuk itu sistem informasi akuntansi sangat dibutuhkan untuk mengantisipasi timbulnya permasalahan di masa yang akan datang dan untuk saat ini sistem diharapkan dapat meniminalisir kendala yang terjadi dan mempermudah proses pengelolaan data piutang usaha pada PT Chandra Putra Globalindo. Nantinya semua proses seperti pengelolaan data barang, pembuatan rincian daftar barang, pengelolaan data daftar pelanggan, pengelolaan data pesanan, pengelolaan transaksi penerimaan dan pelunasan piutang, serta pembuatan laporan penjualan dan pernyataan piutang dapat dilakukan di dalam sistem ini, agar informasi yang dibutuhkan dapat disajikan dengan cepat, tepat waktu dan akurat. Sistem juga akan dilengkapi dengan database sebagai tempat penyimpanan data dan password untuk masing-masing pihak yang bersangkutan sehingga mempunyai hak akses yang berbeda agar data aman dan dapat diakses sesuai kebutuhan. Hasil yang diharapkan dari pembuatan sistem ini adalah dapat mempermudah pekerjaan karyawan dan informasi yang diterima oleh pimpinan lebih akurat dan tepat waktu.

\section{Pembahasan}

Tahapan yang dilakukan pada penelitian ini yaitu dimulai dengan melakukan identifikasi masalah melalui wawancara, observasi dan mempelajari referensi dan dokumen-dokumen yang berkaitan. Tahapan berikutnya yaitu melakukan analisis dengan mengidentifikasi kebutuhan pengguna, selanjutnya melakukan perancangan dan implementasi sistem menggunakan metode terstruktur. Tahapan terakhir yaitu melakukan pengujian terhadap sistem yang telah diimplementasikan menggunakan Standar ISO 9126-1.

Dari hasil wawancara dan observasi dapat diketahui beberapa kendala yang ada pada sistem berjalan dalam proses pengelolaan piutang usaha pada PT Chandra Putra Globalindo, yaitu:

a. Data masih disimpan di dalam file yang sama dengan file peng-input-annya. Peng-input-an setiap transaksi yang terjadi berhubungan dengan datadata yang telah di-input sebelumnya, hal ini dikhawatirkan dapat berakibat pada terhapusnya data-data yang lama secara tidak sengaja dan tidak disadari. Selain itu pengamanan data yang sangat minim mengingat tempat penyimpanan belum menggunakan database, hal ini juga dapat menimbulkan kecurangan dan manipulasi data, karena data sangat rentan diakses oleh pihak-pihak yang tidak bertanggung jawab.

b. Lamanya dalam proses pembuatan laporan. Pada proses pengolahan data piutang dimulai dari penginput-an transaksi ke dalam jurnal dan buku besar pembantu hingga posting ke dalam buku besar piutang serta penyajian laporan membutuhkan waktu yang cukup lama karena harus membuka file transaksi yang sebelumnya terlebih dahulu kemudian mem-postingdatasatu persatu dan harus mengecek data berulang-ulang agar tidak terjadi kesalahan. Hal ini dapat berdampak tertundanya dalam pengambilan keputusan kebijakan usaha yang harus dibuat oleh pihak manajemen untuk mengontrol data piutang usaha dan data yang di sajikan pada laporan menjadi kurang akurat, karena masih sering terjadi kesalahan dan berakibat harus membuat ulang laporan.

\subsection{Analisis Kebutuhan Fungsional}

Dalam merancang sistem pengolahan data piutang, kebutuhan fungsional yang dianalisis adalah sebagai berikut:

a. Bagian Administrasi mampu melakukan login, mengelola data pengguna, daftar pelanggan, data pesanan, retur penjualan dan penerimaan kas.

b. Bagian Administrasi mampu mencetak rincian daftar barang, laporan retur, laporan penerimaan kas, laporan penjualan dan laporan pernyataan faktur yang belum di lunasi (open item statement).

c. Bagian gudang mampu mengelola data barang.

d. Pimpinan mampu login ke sistem dan mencetak laporan penjualan dan laporan pernyataan faktur yang belum di lunasi (open item statement).

\subsection{Analisis Kebutuhan Fungsional}

Spesifikasi kebutuhan perangkat komputer yang dibutuhkan dapat dilihat pada tabel 1 .

Tabel 1. Spesifikasi Kebutuhan

\begin{tabular}{|c|c|}
\hline $\begin{array}{c}\text { Perangkat Keras } \\
\text { (Hardware })\end{array}$ & $\begin{array}{c}\text { Perangkat Lunak } \\
\text { (Software) }\end{array}$ \\
\hline 1. Processor: Intel Core i3 & 1. Sistem operasi \\
\hline 2. Harddisk $500 \mathrm{~GB}$ & Windows 7 atau 8 \\
\hline 3. RAM 2 GB & 2. NetBeans IDE 8.0 \\
\hline 4. Mouse dan Keyboard & (JDK dan JRE 8.0) \\
\hline & 3. $M y S Q L$ \\
\hline & 4. Хатрр \\
\hline
\end{tabular}

\subsection{Perancangan Sistem}

Setelah melakukan analisis dan penelitian dari sistem piutang usaha yang sedang berjalan pada PT Chandra Putra Globalindo, maka akan dibahas mengenai rancangan sistem usulan yang akan dibangun. Sistem informasi akuntansi yang akan dikembangkan ditujukan untuk bagian Administrasi, Gudang dan Pimpinan sebagai pengguna. Use case diagram dari sistem yang akan dibangun dapat dilihat pada gambar 1 .

\subsection{Implementasi Sistem}

Tahapan implementasi sistem merupakan tahap meletakkan sistem supaya siap untuk dioperasikan. Tahap ini termasuk juga kegiatan menulis kode program. Untuk memulai sistem, penguna perlu melakukan login agar dapat mengelola semua kegiatan yang berkaitan dengan pengelolaan piutang usaha. Form login merupakan interface (antarmuka) yang pertama kali muncul saat program aplikasi dijalankan. Pengguna 
aplikasi harus terlebih dulu meng-input nama pengguna (user name) dan mengisi kata sandi (password) dengan benar kemudian klik tombol login, agar dapat masuk ke sistem sehingga dapat menggunakan aplikasi sesuai dengan jabatan dan wewenangnya pada perusahaan PT Chandra Putra Globalindo. Gambar 2 merupakan tampilan dari form login.

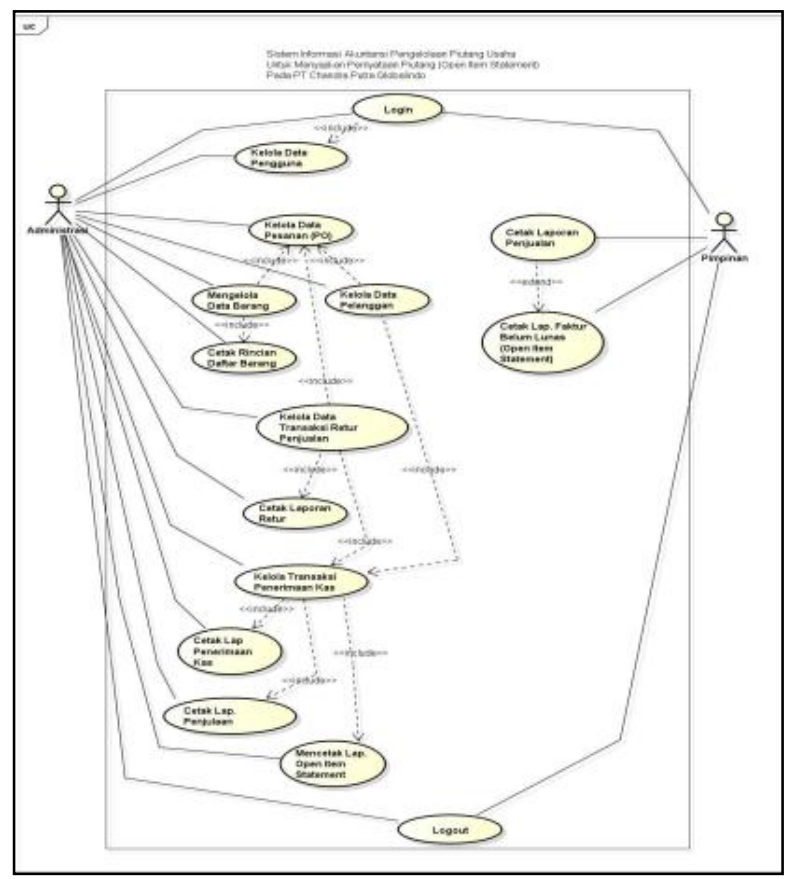

Gambar 1. Use Case Diagram

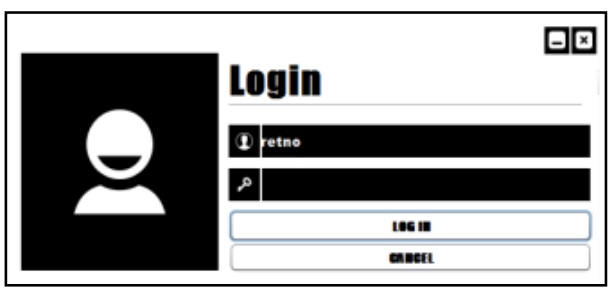

Gambar 2. Tampilan Form Login

Setelah pengguna melakukan login, maka akan muncul tampilan menu utama. Form menu utama administrasi merupakan interface (antarmuka) yang akan muncul ketika pengguna bagian administrasi telah berhasil masuk ke sistem, menu utama berisi beberapa sub-menu antara lain menu pengguna, menu pelanggan, menu pesanan, menu barang, menu penerimaan kas, menu retur, menu penjualan dan menu piutang. Tampilan menu utama dapat dilihat pada gambar 3 .

Kegiatan utama dari sistem ini adalah pengelolaan data piutang yang digunakan untuk meng-input data penerimaan atas piutang (cicilan pembayaran dan pelunasan piutang). Tampilan form pengelolaan data piutang dapat dilihat pada gambar 4. Dari pengelolaan data piutang mampu menghasilkan laporan penerimaan kas, laporan faktur belum lunas dan laporan penerimaan kas. Tampilan masing-masing laporan dapat dilihat pada gambar 5, 6 dan 7.

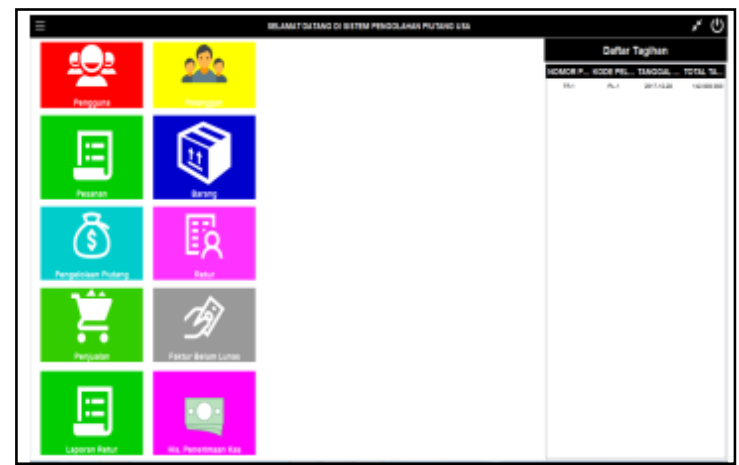

Gambar 3. Tampilan menu utama

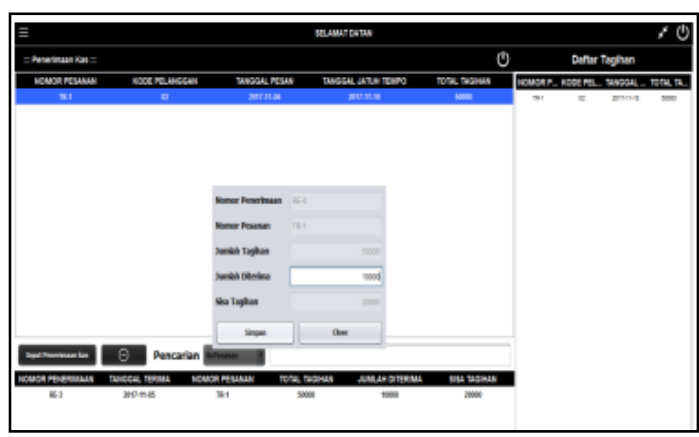

Gambar 4. Form Pengelolaan Data Piutang

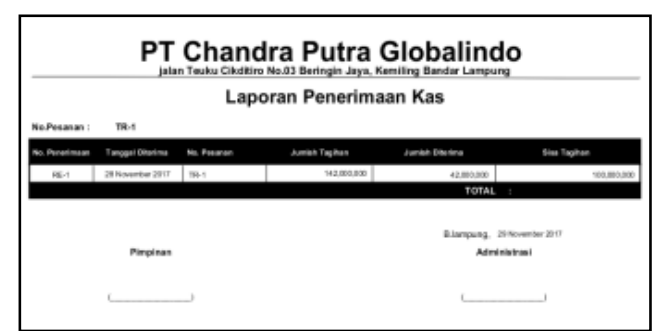

Gambar 5. Tampilan Laporan Penerimaan Kas

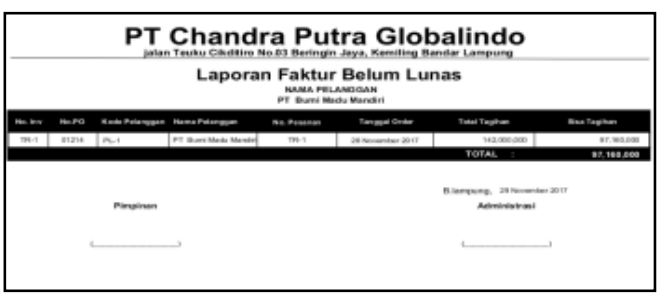

Gambar 6. Tampilan Laporan Faktur Belum Lunas

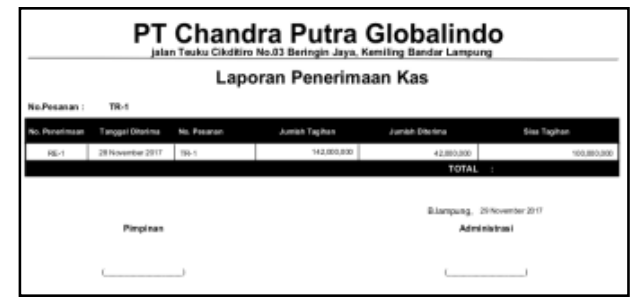

Gambar 7. Tampilan Laporan Penerimaan Kas 
Selain mampu mengelola pengelolaan data piutang, sistem ini juga mampu mengelola data retur atau pengembalian barang yang sudah dibeli oleh pelanggan. Pengelolaan data retur ini hanya dapat dilakukan oleh bagian administrasi. Tampilan form retur dapat dilihat pada gambar 8 .

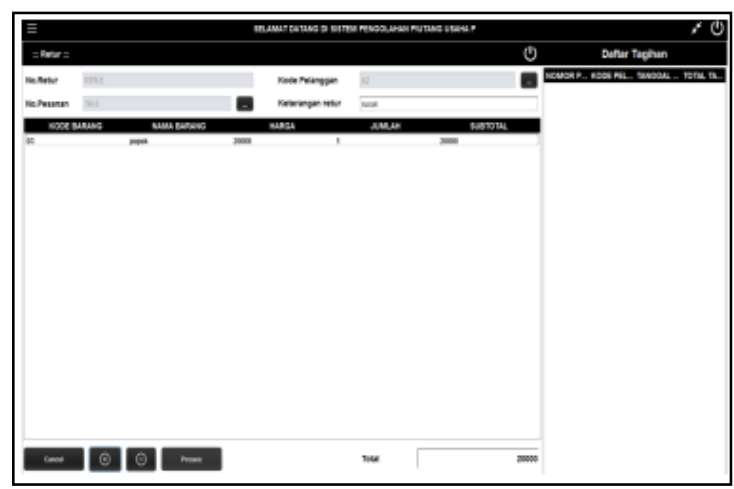

Gambar 8. Form Pengelolaan Data Retur

Dari pengelolaan data retur, mampu menghasilkan laporan retur, laporan ini hanya dapat dilihat dan dicetak oleh bagian administrasi dan pimpinan. Tampilan laporan retur dapat dilihat pada gambar 9 .

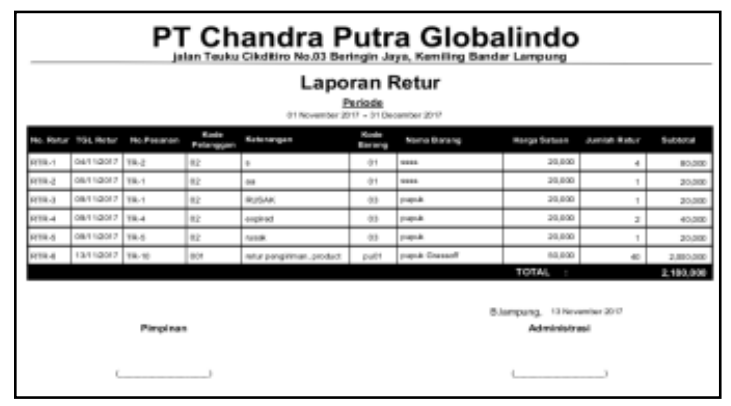

Gambar 9. Tampilan Laporan Retur

\subsection{Pengujian Sistem}

Setiap perangkat lunak yang dihasilkan harus dapat memberikan jaminan kualitas terhadap pengembang dan penggunanya, sehingga perlu dilakukan pengukuran menggunakan standar-standar yang telah didefinisikan (Pressman, 2010). Tujuan dari pengujian sistem adalah untuk mencari kesalahan dari sistem yang dibangun. Salah satu cara yang dapat digunakan untuk pengujian sistem adalah dengan menggunakan Standar ISO 9126-1. Cara ini menerapkan enam karakteristik, yaitu fungsionalitas, keandalan, kegunaan, efisiensi, pemeliharaan dan portabilitas. Kuisoner merupakan salah satu alat yang digunakan untuk mengumpulkan data pengujian sistem. Dari hasil penyebaran kuisoner, hasil penilaian responden akan dihitung persentase kelayakannya dengan menggunakan formula:

$$
\text { Presentase }=\frac{\text { Skor Aktual }(f)}{\text { Skor Ideal }(n)} \times 100 \%
$$

Persentase kelayakan yang diperoleh kemudian dibandingkan dengan tabel konversi yang berpedoman pada acuan konversi nilai. Tabel konversi nilai dapat dilihat pada tabel 2 .

Tabel 2 Tabel Konversi Nilai Presentase Kelayakan

\begin{tabular}{|l|l|}
\hline \multicolumn{1}{|c|}{$\begin{array}{c}\text { Presentase Pencapaian } \\
(\%)\end{array}$} & \multicolumn{1}{|c|}{ Interpretasi } \\
\hline $90 \leq \mathrm{x}$ & Sangat Baik \\
\hline $80 \leq \mathrm{x}<90$ & Baik \\
\hline $70 \leq \mathrm{x}<80$ & Cukup \\
\hline $60 \leq \mathrm{x}<70$ & Kurang \\
\hline $\mathrm{x}<60$ & Sangat Kurang \\
\hline
\end{tabular}

Keterangan:

$\mathrm{x}$ : Presentase hasil pengujian

Dari hasil penyebaran kuisoner dengan 23 pertanyaan kepada 15 responden, diperoleh hasil sebagai berikut (gambar 10):

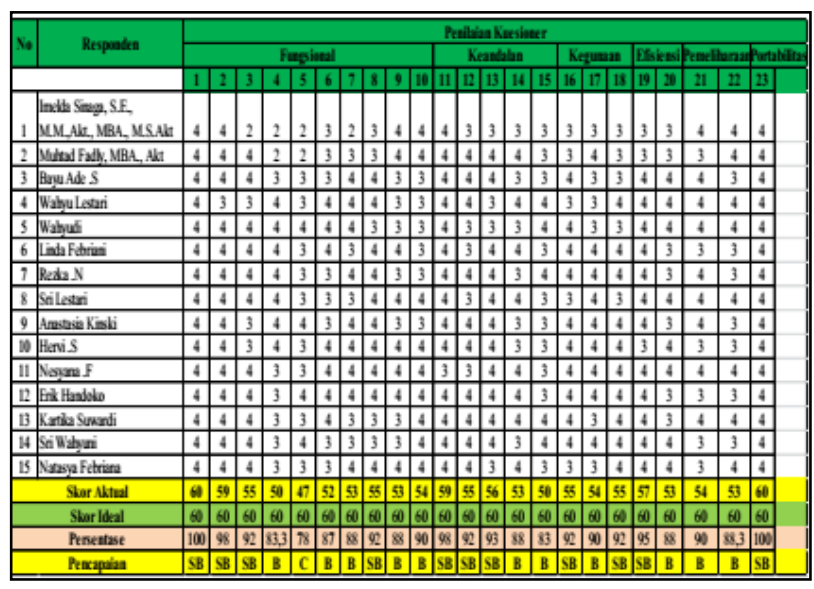

Gambar 10. Hasil Pengolahan Kuisoner

Keterangan:

SB : Sangat Baik

B : Baik

C : Cukup

Berdasarkan gambar 10, diperoleh nilai rata-rata untuk skor aktual sebesar 54,43. Dengan menggunakan formula penghitungan presentase kelayakan, maka diperoleh nilai kelayakan dari sistem yang dibangun adalah sebesar 90,72\%. Nilai presentase tersebut jika dikonversi maka akan masuk ke dalam kategori "sangat baik". Yang berarti bahwa sistem tersebut sangat layak untuk diterapkan dalam pengelolaan data piutang.

\section{Kesimpulan}

Berdasarkan hasil pembahasan sebelumnya menunjukkan bahwa kendala yang dihadapi dalam proses pengelolaan piutang usaha pada PT Chandra Putra Globalindo antara lain dalam membuat laporan pernyataan piutang masih dilakukan posting manual satu persatu untuk setiap debitur sehingga menimbulkan keterlambatan dalam penyajian informasi serta saat pencarian data penting membutuhkan waktu yang lama karena penyimpanan data belum menggunakan database dan masih menggunakan arsip manual sehingga memungkinkan data hilang, pemborosan ruang 
penyimpanan serta data mudah diakses oleh seluruh karyawan yang memungkinkan terjadinya kecurangan dan manipulasi data. Dalam jangka panjang akan menyulitkan perusahaan ketika perusahaan semakin maju dan berkembang.

Sistem pengelolaan data piutang yang dibangun mampu melakukan pengelolaan data pengguna, pengelolaan data barang, mencetak rincian daftar barang, pengelolaan data daftar pelanggan, pengelolaan data pesanan, pengelolaan data retur, pengelolaan transaksi penerimaan dan pelunasan piutang serta berdasarkan data yang tersimpan dalam database dapat menghasilkan laporan penjualan dan laporan faktur yang belum lunas (open item statement). Sehingga informasi yang dibutuhkan dapat disajikan dengan cepat, tepat waktu dan akurat. Sistem dibangun menggunakan bahasa pemrograman Java dan database MySQL sebagai tempat penyimpanan data.

\section{Daftar Pustaka}

Hendarti, H dan Margaretta, F. 2008. Analisis dan Perancangan Sistem Informasi Akuntansi Penjualan. Staff Pengajar Fakultas Ilmu Komputer, Universitas Bina Nusantara. Jakarta.
Hery. 2016. Akuntansi Dasar 1 \& 2 : Edisi National Best Seller. Jakarta : PT Grasindo.

Noerlina, N dan Ratna. 2006. Analisis dan Perancangan Sistem Informasi Akuntansi Penjualan dan Piutang Dagang Studi Kasus PT SAAG Utama. Program Studi Komputerisasi Akuntansi, UBINUS. Jakarta.

Pressman, Roger S. 2010. Software Engineering: A Practitioner's Approach, Seventh Edition. McGraw-Hill. Americas, New York.

Sidik, Achmad dan Widiawati, Iis. 2016. Rancangan Sistem Informasi Pengelolaan Piutang Dengan Metodologi Berorientasi Objek (Studi Kasus di PT Shinta Woo Sung). Jurnal Sisfotek Global, Vol. 6 No. 17.

Sukendar, Heri dan Selvia. 2010. Sistem Informasi Akuntansi Penjualan, Piutang dan Penerimaan Kas pada PT Nakami Kiema Cemerlang. Jurusan Akuntansi, Fakultas Ekonomi dan Bisnis, Universitas Bina Nusantara. Jakarta. 